\title{
Collaboration after Conflict: A Lesson from Collaborative Action in Customary Land Tenure Conflicts in Lombok, Indonesia
}

\section{Aryogito Nindyatmoko ${ }^{1}$, Kristina Setyowati ${ }^{1, *}$, and Rina Herlina Haryanti ${ }^{1}$}

\section{AFILIATIONS \\ 1. Faculty of Social and Political Sciences, Universitas Sebelas Maret, Surakarta, Indonesia Correspondence: kristina@staff.uns.ac.id}

RECEIVED 2021-06-05

COPYRIGHT @ 2022 by Forest and Society. This work is licensed under a Creative Commons Attribution 4.0 International License

\begin{abstract}
Land tenure conflicts in Lombok occured due to social interactions between community and state institutions. These were triggered by the unilateral claims of some of the villagers of Bebidas who acted on behalf of indigenous communities to take back what they believed to be their ancestral land in the Mount Rinjani National Park area. This paper analyzes how stakeholders generated conflict resolution efforts that emphasized inclusive efforts by collaborative action through dialogue based on collaborative governance theory. Data were obtained from interviews with several key informants from various levels of government, as well as members of the Bebidas village community and NGO representatives. Documentation and observation were also carried out to obtain data validity over sustained data collection and analysis process. Findings show that conflict resolution resulted from a longterm process that built up from dialogues involving various stakeholders, which encouraged the emergence of Mutual Agreements and Memorandum of Understanding as milestones to end conflicts. This helped to initiate peaceful relations. Findings suggest that capacity building, promoting awareness, and technical training to support rights and livelihoods on an ongoing basis help to address conflicts rooted in knowledge imbalances. In addition, expanding conservation partnership through community empowerment and ecosystem restoration programs assist in maintaining resources and supporting economic benefits underpin ideals of sustainable longer term uses of the Rinjani.
\end{abstract}

\section{KEYWORDS}

conflict resolution; collaborative action; national park; collaborative governance; land tenure

\section{INTRODUCTION}

As one of the countries with the largest tropical forest areas in the world, Indonesia is still facing significant deforestation challenges. Some of the most complex problems are related to land and forest tenure conflicts (Fisher et al., 2017). Tenure conflicts over land and other natural resources in Indonesia are similar to the metaphor of the iceberg, whereby challenges may look simplified from the surface, but they are a factor of a complex set of networks and interconnected issues below the surface (Wirawan et al., 2019). From 2010 - 2019, there were more than 3,000 forestry-related agrarian conflicts recorded (Lokadata, 2019). Land tenure according to Larson (2013), is related to a complex set of dimensions related to questions of who owns land, who uses, manages, and decides resources.

In this study, we focus on conflict claims on customary land tenure dynamics in Bebidas Village, Lombok, Indonesia, which was a conflict that arose due to social interactions between communities and the state. It began when several individuals in Bebidas cleared more than 100 hectares in Mount Rinjani National Park (MRNP) on the 
basis of unilateral Indigenous land claims. They did this by naming their community the 'Jurang Koak Indigenous Land Defenders' (JKILW) or 'Pejuang Tanah Adat Jurang Koak'. This act is considered prohibited by Law No. 41 of 1999 on Forestry, stating that all citizens or parties are prohibited from 1) encroaching on the forest, 2) occupying forest areas illegally, 3) cutting trees down without having the right or permission from related officials. The community aiming to occupy the land for small-scale agriculture purposes, as well as settlements by building several semi-permanent buildings. Furthermore, the cleared areas were thereafter utilized as a tourist destination called the 'Jurang Koak Indigenous Land Tourism' or 'Wisata Tanah Adat Jurang Koak'. The name Jurang Koak is taken from one of the hamlets in Bebidas.

In the early phase of the conflict, the government tended to use a law enforcement approach. In 2015, various efforts were made to remove people living in the encroachment areas; by arresting those who are considered to be 'provokator.' However, the law enforcement approach ended in clashes and rejection of local authorities who were considered by local residents to be taking undue repressive actions. In the same year a guard station belonging to the Mount Rinjani National Park Board (MRNPB) was damaged by some people as a reaction to the law enforcement activities by local authorities. From 2015-2018, conflicts continued to occur, marked by resistance and clashes between Bebidas residents and local authorities. The more the parties want to dominate other interests, the increasingly polarized the situation became.

Efforts ensued to resolve the Bebidas conflict in a collaborative and integrative way, by sitting together and intentionally conveying perspectives in a forum. The definition of conflict resolution is based on the idea of overcoming conflict at the root of the problem, in a way that addresses triggers and involves conflicting parties in settling grievances by eliminating the perceived mismatches between goals and interests and building new situations that are deemed appropriate (Burton, 1988; BarTal, 2000; Katz \& McNulty, 1994). Moreover, the concept of conflict resolution in the context of public administration is also to resolve conflict through established forms and functions of government, mandated (authorized) to handle conflicts (Zartman \& Faure, 2005). The approach in conflict resolution puts forward dialogical methods that can accommodate and involve both the state and other non-state groups in making policies that are considered more equitable, because parties can hear out aspirations directly from across various stakeholders groups (Ansell \& Gash, 2008; Emerson et al., 2012). Previous research also supports notions of collaborative action a s an organizing principle or solution for land and forest tenure conflicts, because it emphasizes conflict resolution efforts that contain inclusive, open and fair governance values (Werner, 2018; Elfversson, 2016; Silima, 2016; Gabay \& Alam, 2017; Pritchard, 2016; Kalabamu, 2019; Lombard, 2016; Purnomo \& Anand, 2014; Larson et al., 2013; Sahide et al., 2019).

The concept of collaborative governance can be applied to conflict resolution in various ways, and in this paper we are particularly interested in situations that involve protected area management, and more broadly those that relate to complex socioecological system dynamics and wicked problems involving land tenure and infrastructure and economic interests that can create competing dilemmas between environment and development (Dhiaulhaq et al., 2015; Fisher et al., 2017 Kossmann et al., 2016). Fisher, et al. (2020) argues that through the application of collaborative governance, natural resource management institutions build the capacity of stakeholders, including indigenous groups, to navigate existing conflict resolution 
mechanisms. Moreover, Kossmann, et al. (2016) states that collaborative governance assists in solving public problems through "regular involvement of actors including communities, NGOs and all levels of government with the aim of supporting the effectiveness of governance." Furthermore, as a principle, Ansell \& Gash (2008) state that "it is very difficult to imagine collaborative action without face-to-face dialogue." Thus, the objective of this article is to analyze how the principles of collaborative governance are applied in dynamic interactions involving customary land tenure conflict in Bebidas through intensive dialogues that can be used as an effective means for conflict resolution.

\section{THEORETICAL FRAMEWORK}

This research is based on a collaborative governance theoritical framework adopted from Emerson \& Nabatchi (2015) and Emerson, et al. (2012) who analyze a very complex set of social interactions consisting of three main dimensions: principled engagement, shared motivation, and capacity for joint action. Principled engagement is defined as ways in which parties from different backgrounds, identities, and interests work across perspectives to jointly solve problems through dialogue designed in an inclusive, fair, and opened communication system. The first aspect of principled engagement is 'discovery' in which views and perspectives of conflict faced by each participant are revealed. Then they share and classify common goals and expectations for collaboration in a dynamic process, which is called 'definition'. Through intensive communication and dialogue, each of the parties answers, listens, and expresses opinions honestly in 'deliberation.' Successful collaboration will generate 'determinations' such as procedural decisions and administrative protocols.

The second dimension, 'shared motivation', is often equated with social capital, which refers to the ways in which each participant in a collaboration builds trust, understanding, and commitment, as well as how they can solve problems in the most effective and efficient way. It begins with a process described as 'mutual trust', relating to the way that participants collaborate in acts that are mutually acceptable, predictable, and interdependent to each other. This then forms the basis of 'mutual understanding' by expressing the attitudes to be able to understand each other and respect the position and interests of other stakeholders. In turn, mutual understanding generates 'internal legitimacy', referring to the collaboration process, which must fulfill overarching principles of being representative, fair, transparent, accepted to all parties, legitimate and motivated by longstanding goals of sustainable collaboration. Legitimacy leads to creating bonds of 'shared commitment' which enables parties to work together across sectoral boundaries of each interest group and commit to establishing some common paths forward.

Collaboration should thus generate new capacities to create effective actions that link strategy and performance, which is known as the 'capacity for joint action'. The first capacity is an 'institutional and procedural arrangement,' relating to the way that parties play a particular role and how they implement it in a shared organization. 'Leadership' is also a capacity building element associated with collaboration, in terms of sponsorship, facilitation, mediation, and engagement of expert roles. The third element is 'knowledge,' which in this case refers to an integrated set of values in raising awareness. Collaboration thus creates the capacity for 'resources' to be combined addressing challenges of potentially scarce resources, including: funding, time, staff, logistical and technical assistance, and administrative and organizational 
requirements. The three dimensions of principled engagement, shared motivation, and capacity for joint action generate outputs of collaborative action and is rooted the heart of a collaborative governance framework. These elemental aspects are usually described as 'small wins' because this stage is what each participant aims for as they agree to work together in complex interactions to resolve conflict. As Emerson \& Nabatchi (2015) express, collaborative action is a mechanism to reach agreement, issue new mutual regulations, or form new organizations.

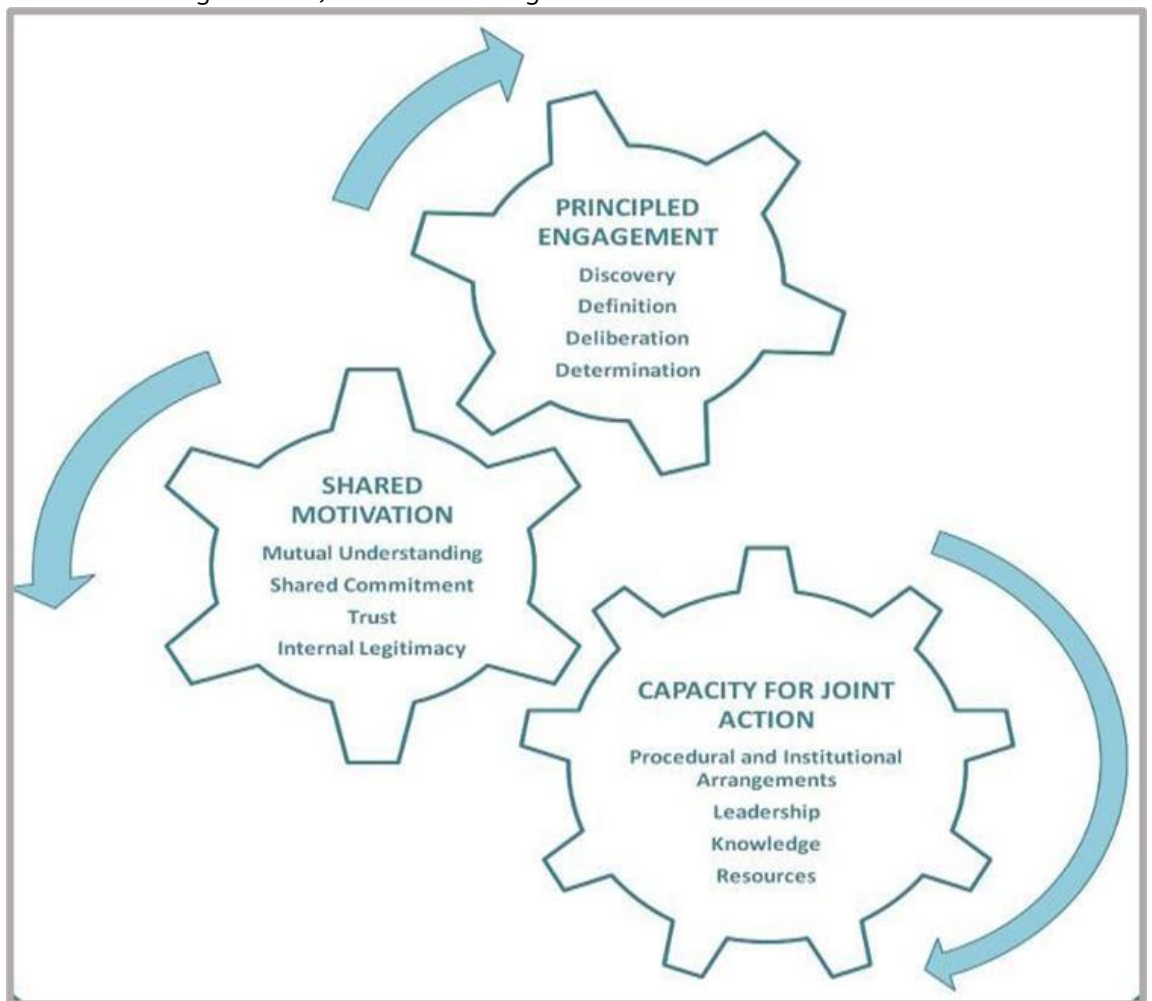

Figure 1. Collaborative Governance Framework, adapted from (Emerson \& Nabatchi, 2015)

\section{METHODS}

\subsection{Study Area}

The area described (Bebidas) in the introduction involves a region in East Lombok which is part of MRNP, located at the south eastern tip of the park area (as shown in figure 2). Part of Bebidas village area was cleared by around 105 hectares as shown in figure 3 with red color. Historically, Mount Rinjani was designated as a Wildlife Reserve area during the Dutch colonial era through Staatsblad No. 77 in 1941. In 1979, the boundaries of the Mount Rinjani Wildlife Reserve were rearranged to become 40,000 hectares encompassing the areas of West Lombok, Central Lombok, and East Lombok.

In 1990, the status of Mount Rinjani Wildlife Reserve was changed to the MRNP designation based on Decision of the Minister of Forestry No. 448 / Menhut-VI /19 90 on March 6, 1990. In 2005, an additional area of MNRP was added, as evidenced by the 
issuance of Decision of the Minister of Forestry No. SK.298 / Menhut-II / 2005 stipulating the TNGR forest area to encompass 41,330 hectares. Zoning systems were thereafter developed for the first time in 2005 and again revised in 2016 and 2017 (see figure 3).

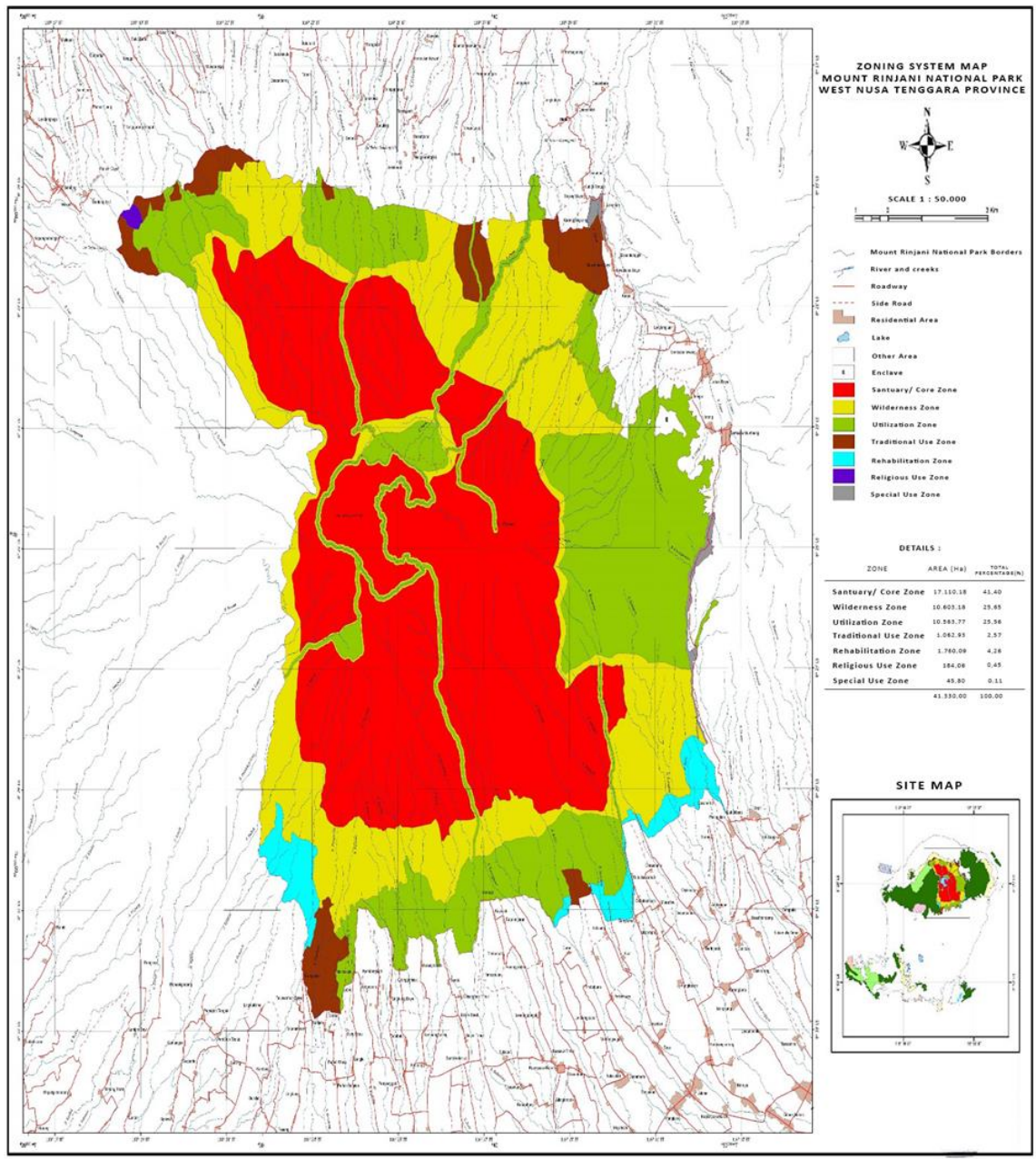

Figure 2. Zonning System Map in 2017 of MRNP, source: MRNPB archive (modified).

\subsection{Data Collection and Analysis}

Three ways of data collection were employed to assist in investigating the ways principles of collaborative governance were applied in this tenurial conflict resolution process. These include interviews, documentation, and participant observation. Primary data were obtained from interviews conducted with twelve key informants from eight elements covering the village, sub-district, regional, and central levels of government, as well as the police, military, community, and NGO (table 1 shows the characteristics of the interviewed informants). The interviews were recorded with permission and each interview took approximately 25 - 45 minutes. The interview time frame took place from 
December 2020 to February 2021. This study used a question guide that was extracted from the theoretical framework adopted from (Emerson \& Nabatchi, 2015). The interview result was analysed by coding to categorize and classify and elicit key dimensions of the theoretical framework.

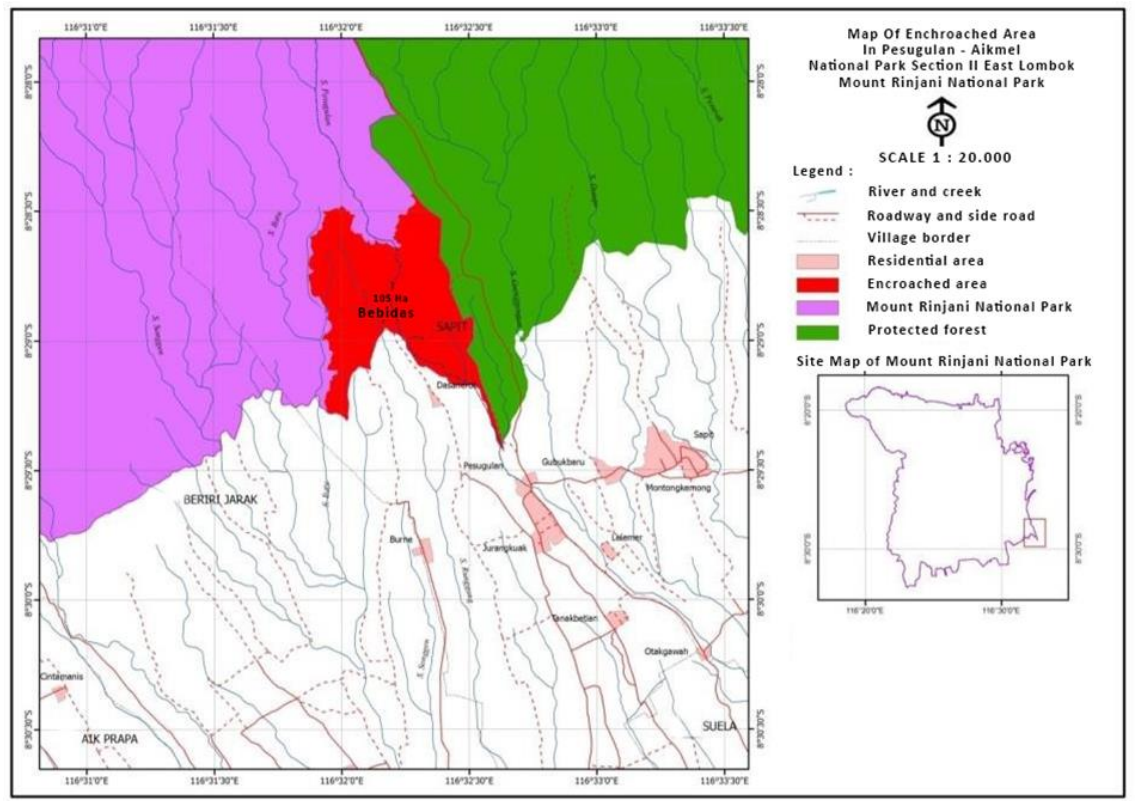

Figure 3. Map of Enchroached Area, source: MRNPB archive (modified)

Document interpretation was also conducted to enrich data analysis. Several documents were obtained from online media portals using the keywords "Bebidas village forest encroachment", "Bebidas village conflict", "Bebidas customary land conflict" to understand overall background of the conflict, especially the ways in which it has been portrayed in the media. File tracing was also carried out, by obtaining incident reports and meeting reports related to the Bebidas conflict, Forestry Regulation and documents related to the agreements reached. Meanwhile, the participant observation was conducted through joining in patrol activities, attending meetings with several stakeholders, and engaging in local training initiatives for the community. Participating in some of these activities helped increase the opportunity to see first- hand situation how the conflict resolution process unfolded and to relate how the lived experiences assist in shaping the data analysis.

The step for data analysis included collecting data, organizing, sorting, and selecting data into groupable units and then synthesizing, looking for and finding patterns, themes, and common threads that can be drawn to form a structured conclusion. Therefore, condensation of the data is used so that the complexity of the data generated can be summarized according to the themes listed out in the theoretical framework and reduces those factors which are not relevant to a particular categorical distinction.The data was then grouped and clarified, cross-checked with relevant documents and observations to form a valid and accountable conclusion of the collaborative conflict resolution process based on the three concepts of 'principled engagement', ' shared motivation' and 'capacity for joint action.' 
Table 1. Stakeholders Involved in the Interviews

\begin{tabular}{|c|c|c|}
\hline Sectors & $\begin{array}{c}\text { Total } \\
\text { (people) }\end{array}$ & Roles/Authorities \\
\hline $\begin{array}{l}\text { Mount Rinjani National } \\
\text { Park Board (MRNPB) }\end{array}$ & 3 & $\begin{array}{l}\text { Managing the MRNP area, approving regulations and } \\
\text { budgets, conducting joint patrols, encouraging } \\
\text { dialogue between organizations / parties }\end{array}$ \\
\hline $\begin{array}{l}\text { Bebidas Residents (ex- } \\
\text { member JKI LW) }\end{array}$ & 3 & $\begin{array}{l}\text { Making claims over customary land in the MRNP area } \\
\text { but then involved in forest restoration programs }\end{array}$ \\
\hline $\begin{array}{l}\text { Bebidas Village } \\
\text { Administration }\end{array}$ & 1 & $\begin{array}{l}\text { Overseeing development initiatives, and providing } \\
\text { dialogue opportunities }\end{array}$ \\
\hline $\begin{array}{l}\text { Wanasaba Sub-District } \\
\text { Administration }\end{array}$ & 1 & $\begin{array}{l}\text { Empowering Community and instituting peace and } \\
\text { public order }\end{array}$ \\
\hline Babinsa (Military) & 1 & Conducting extension and collection of information \\
\hline Police & 1 & $\begin{array}{l}\text { Enforcing the law, maintaining security and providing } \\
\text { protection }\end{array}$ \\
\hline Local Government & 1 & $\begin{array}{l}\text { Conducting coaching, evaluation, control, extension } \\
\text { and providing dialogue opportunities }\end{array}$ \\
\hline NGO & 1 & $\begin{array}{l}\text { Raising awareness, consulting public, building } \\
\text { capacity }\end{array}$ \\
\hline
\end{tabular}

\section{RESULTS}

\subsection{Understanding the Origins of the Problem}

This research reveals how each stakeholder expressed their views and perspectives on what actually happened in the conflict over customary land tenure claims in Bebidas. According to one perspectivem the conflict occurred when a group of community members began to occupy the MRNP area: Local government informants noted: "in my opinion there are community groups who wanted to take over the forest land. ... A second issue then ensues, as certain group interests take advantage of the situation... and certain groups begin to act in the name of poverty, on behalf of the people's interests, and helps them strengthen their claims to control the forest area ..." (local government). Meanwhile, perspectives from Bebidas village express they were trying to find livelihoods from the forest since they live so close to the Rinjani conservation area. They consider Rinjani as an ideal site for small-scale agricultural land. In some respects there was a lack of understanding regarding conservation regulations and formal law, which was exacerbated by acts of a former village head who provoked residents to encroach lands: "... at first it was a community group driven by the former village head... they entered the area saying that it was not part of the national park area... but now they have changed the narrative saying they want to control it in a sustainable manner and that's when the idea of customary land claims emerged..." (Head of Bebidas Village Administration)

The community also believed that there was a tomb of their ancestor in the MRNP area. However, it turns out that the claims for the ancestral grave were weak and tended to lead to manipulation because after joint-checking by MRNP, Bebidas villagers and leaders, sub-district representatives, local governments, and the police, it was determined that there were no graves, but only piles of stones. In one testimony by an ex-member of the group that made the claims to customary land, he stated: "The contents were only a pile of stones. I know there were no graves there because I myself helped to dig, and I know there was never any graves there..." Furthermore, the former head of the village administration utilized this opportunity for his own political 
interests, namely to promote his election for village head that took place in 2018 . He had tied his election to the promise of gaining more community controlled land.

Closer analysis and discussion with the community revealed a general sense that the claims to customary land were weak, with many considering the approach to benefit only a few people in Bebidas village. This effort was pursued through the formation of Jurang Koak Indigenous Land Defenders (JIKILD), and it was based on two main factors: 1) economic factor driven by limited community access to fertile land for their livelihood and exacerbated by the lack of knowledge and understanding of Park regulations, which then made it easy to provoke them to join the cause ; 2) political ambitions caused by the interests of the former head of Bebidas village who designed a community movement to garner sympathy and support with the intention of winning the 2018 election.

\subsection{Defining Collaboration as a Solution}

The government made efforts to address the conflict. However, at the outset, authorities took a heavy-handed approach through law enforcement measures to immediately resolve the problem. Early proponents acknowledged that this approach failed. Therefore, in 2015, the conflict culminated with clashes between the government and the community, leading to the arrest of several people who were considered riot perpetrators and provocateurs. Over time there was increasing consensus that a collaborative approach was needed.

Considering that the conflict was growing more embittered and complex collaborative actions aimed to convene all parties in order to facilitate peaceful outcomes: "The dialogue forum supported the generation of public awareness that what [the community] had done was wrong, and that the encroachment had damaged many natural functions in the area, including spring water. For this reason, it was proposed to look for patterns of how to use natural resources together between government and community to generate a win-win solution" (Head of Wanasaba sub-district administration).

The East Lombok regional government also expressed their views: "Yes, the goal is of course to save the forest ... if the forest is controlled by individuals, then it is not only the people around that area that will suffer losses, but the people outside the area also feel so..." Likewise, the community viewed collaboration as a considerable solution: "The search for a solution to this conflict, the conflict between the community and the National Park ... [MRNP] offered collaborative action as a way to work together in the area. This means that the community can have options to work there, but are prohibited from changing the formal status of the land. That iswhat was offered to us..." (Bebidas Resident).

The statements clearly show that collaboration forums through dialogue, meetings, and other forms of communication were able to respond to the conditions of this conflict It had three main functions: 1) as a forum for listening to each other's interests and demands, 2) as a forum for dissemination of understanding and knowledge about the importance to take action immediately to restore forests and stop encroachment, 3) a forum for producing solutions based on collective action.

\subsection{Stakeholders Identification dan Face-to-face Dialogue held}

The settlement of this conflicts rested on intensive communication through formal and informal dialogues designed to encourage stakeholders to sit together to hear and respond directly to the perspectives of all parties. Several participants were 
intensively involved in dialogue forums both formal and informal, namely with the MRNP, the village government of Bebidas, Wanasaba District, the East Lombok regional government, the Bebidas community, local police, Babinsa (military), and NGOs. Apart from that, there were several parties involved sporadically, such as Environment and Forestry Service (EFS), Natural Resources Conservation Center (NRCC), National Land Agency (NLA) and the Judiciary. At least 8 formal meetings were held during 2015-2020 to resolve this conflict. The following is the timeline of meetings.

Table 2. Timeline of Meetings/Dialogues that have been held

\begin{tabular}{|c|c|c|c|c|}
\hline No & Date & Location & Agenda/Results & Stakeholders \\
\hline 1 & Jun-15 & $\begin{array}{l}\text { The MRNP } \\
\text { encroachment } \\
\text { area }\end{array}$ & $\begin{array}{l}\text { Urging Bebidas villagers to stop } \\
\text { land clearing at the onset of the } \\
\text { conflict, but the community } \\
\text { refused }\end{array}$ & $\begin{array}{l}\text { Police, MRNP, } \\
\text { Military, and } \\
\text { Bebidas residents. }\end{array}$ \\
\hline 2 & Aug-15 & $\begin{array}{l}\text { MRNP Office in } \\
\text { East Lombok }\end{array}$ & $\begin{array}{l}\text { Resolving the conflict by focusing } \\
\text { on persuasive efforts (dialogue } \\
\text { and meetings) and offering } \\
\text { solutions by empowering } \\
\text { communities through tourism } \\
\text { management and regional } \\
\text { recovery program }\end{array}$ & $\begin{array}{l}\text { Local } \\
\text { Government, } \\
\text { Judiciary, Police, } \\
\text { MRNP, Bebidas } \\
\text { community }\end{array}$ \\
\hline 3 & Oct-15 & EFS office & $\begin{array}{l}\text { Hearing community demands, } \\
\text { providing understanding, } \\
\text { requesting people to stop } \\
\text { encroaching and offering to } \\
\text { collaborate instead of conflict }\end{array}$ & $\begin{array}{l}\text { MRNP, community } \\
\text { representatives } \\
\text { and EFS }\end{array}$ \\
\hline 4 & Aug-17 & $\begin{array}{l}\text { Local Police } \\
\text { office }\end{array}$ & $\begin{array}{l}\text { Delivering results and plans of } \\
\text { law enforcement activities and } \\
\text { designing community } \\
\text { empowerment initiatives }\end{array}$ & $\begin{array}{l}\text { Local Police, } \\
\text { MRNP, NLA, } \\
\text { NRCC, community }\end{array}$ \\
\hline 5 & Oct-17 & $\begin{array}{l}\text { Wanasaba Sub- } \\
\text { district Office } \\
\text { Hall }\end{array}$ & $\begin{array}{l}\text { Inviting the community to } \\
\text { manage tourism rather than } \\
\text { encroaching and destroying the } \\
\text { forest, without positive results }\end{array}$ & $\begin{array}{l}\text { Local } \\
\text { Government, } \\
\text { MRNP and } \\
\text { community } \\
\text { representatives }\end{array}$ \\
\hline 6 & Jan-18 & $\begin{array}{l}\text { The } \\
\text { encroachment } \\
\text { area }\end{array}$ & $\begin{array}{l}\text { Inviting and convincing the } \\
\text { community to take part in the } \\
\text { ecosystem restoration program, } \\
\text { where the community gets a } \\
\text { decent wage instead of } \\
\text { continuing to clear the forest. }\end{array}$ & $\begin{array}{l}\text { Sub-district and } \\
\text { village } \\
\text { government, } \\
\text { MRNP, the } \\
\text { community }\end{array}$ \\
\hline 7 & Oct-18 & $\begin{array}{l}\text { MRNP Office } \\
\text { Hall }\end{array}$ & $\begin{array}{l}\text { Through better understanding of } \\
\text { the issue, t he community began } \\
\text { to realize that they had been } \\
\text { manipulated by unscrupulous } \\
\text { individuals and asked the MRNP } \\
\text { to take firm action against these } \\
\text { individuals by enforcing the law. }\end{array}$ & $\begin{array}{l}\text { MRNP, village } \\
\text { administrators, } \\
\text { local government, } \\
\text { Bebidas } \\
\text { community and } \\
\text { NGO }\end{array}$ \\
\hline 8 & Aug-19 & $\begin{array}{l}\text { The } \\
\text { Encroachment } \\
\text { area }\end{array}$ & $\begin{array}{l}\text { Re-inviting the community to } \\
\text { participate in the ecosystem } \\
\text { restoration program, resulting in } \\
\text { most of the encroachers exiting } \\
\text { the area and a willingness to join }\end{array}$ & $\begin{array}{l}\text { MRNP, Local } \\
\text { Government, } \\
\text { Police, village } \\
\text { administrator, the }\end{array}$ \\
\hline
\end{tabular}




\begin{tabular}{|c|c|c|c|c|}
\hline No & Date & Location & Agenda/Results & Stakeholders \\
\hline & & & $\begin{array}{l}\text { the program offered by virtue of a } \\
\text { verbal agreement }\end{array}$ & $\begin{array}{l}\text { community and } \\
\text { NGO }\end{array}$ \\
\hline
\end{tabular}

\subsection{Conflict Resolution Process through Collaborative Actions}

Various dialogues were conducted in which the parties proceeded to build trust, understanding, legitimacy and commitment as important components in a successful dialogue. Trust and understanding are built with intensive communication: "In my opinion, the first is assistance, such as frequently gathering with residents. Informal meetings were really important ... then both routine and intensive engagement, which resulted in development of real solutions ... this made them feel appreciated as part of the solution" (MRNP staff). Likewise, the government built trust by involving the community in some activities: "The community was invited to dialogue with officials, invited to understand the issues together based on facts. Then they were notified of forest rehabilitation initiatives being promoted, to which community was involved. This awareness began to spread within the community and across stakeholder groups ..." (Local Government). Even though the dialogues were pursued intensively and involved all stakeholders, in fact there were still objections, especially among the community. "Yes, I understand what happened ... and the MRNPB insisted on maintaining the Ministerial Decree ... so we have no options in the end. The mediation did not go as expected..."(Bebidas resident). This stagnation in negotiations was due to the strong influence of the former village head figure who continued to pressure the community and undermined efforts at collaboration so that they could not be implemented.

The year 2018 was a turning point in settling conflict. The community's trust toward the government began to increase. The influence of the former village head had begun to wane because he lost the 2018 election. This is also linked to the position of the current elected village head of Bebidas, urging to cooperate with the authorities to tackle this problem immediately: "In 2018, it was the peak of political intensity. I [Head of Bebidas village] was elected and have tried to be persuasive to my community to help the National Park [MRNP] to restore its original conditions. We do this by trying to regulate the activities in the Park and trying to influence behaviors of people ..." (Bebidas village head). As a result, the tensions have subsided. This is indicated by the presence of several former JKILD members who began to collaborate with government stakeholders. On former member noted: “... after we left [ JKILD] we were recruited by the government, to join the Rinjani CFP [Community Forestry Partners], and we began to understand better what national park is, but this needed a long process ..." (Bebidas Resident). The collaboration between the government and the community encouraged partnerships, because there were divisions within the community which created pro and con groups. Partnership arrangements helped to eliminate the groupings of both pro and con groups, and even the leader of the con group who used to reject and fight any initiative has come to embrace working relationship to get involved in activities and programs that have been designed to restore the condition of the Rinjani forest.

The partnerships encouraged the formation of new community groups: "There is a group now called the 'Kelompok Sadar Lingkungan/Pokdarling' [community-based forest management], who manage 50 hectares that benefit the welfare of the community ... I am sure the people will serve to benefit a lot from this" (Bebidas Resident). The community gets paid from ecosystem restoration activities as well, that complies with standards set by the government, "we invited our local community to 
participate in reforestation [planting activities] with a wage per person per day of Rp 125,000..." (Beidas Resident). Besides that, 'Kelompok Sadar Wisata/Pokdarwis' was also formed (community-based tourism management): Pokdarwis is more about managing tourism, so MRNP areas that have tourism potential, can be managed according to the rules... like in Propok... "although Non-Tax Revenues are paid to the State"(MRNPB staff).

It can be said that conflict resolution through dialogue and negotiation requires a long process because there are many obstacles, which were exacerbated by "bad actors" that for a period created misinformation and misled the community. However, continuous communication efforts were able to build knowledge and understanding of the importance of protecting and preserving Rinjani conservation areas. It also developed mechanisms for benefiting local stakeholders so that the community gradually retreated from encroaching on the forest, and furthermore, now supports restoration efforts through forest programs that are supported by the government.

\subsection{Reaching Agreements through Collaborative Action}

Several agreements have been reached as a way to create a new relationship from conflict to collaboration. One of the agreements resulted from the collaborative process in the form of signing a Mutual Agreement (MA) between the MRNP and the East Lombok Regent: "The agreement was reached first with the local government, then with the regent in a statement called 'Meriri Tuah Rinjani Bestari'... 'Meriri' refers to an act of fixing something, while 'tuah Rinjani' means that there are greater benefits to all, while 'bestari' is a signifier that highlights that they are being done in a good way. That's what the regent said: 'let's fix Rinjani together'..." (MRNPB staff). This agreement is intended to protect Rinjani, which has since received added attention in the form of a Geopark and Biosphere Reserve based on its role as a center of spiritual activity, nature tourism development activities, environmental services, and cultural preservation that provides benefits to the lives of the Sasak, the Lombok Indigenous people).

Another agreement that was successfully reached included the signing of the MoU between MRNP and the representatives of the Bebidas village community: "the MOU was made ...to provide legal standing... what was regulated, for example, included a location that could be utilized. There are definite boundaries, which can be managed by certain jurisdictions and communities ... and there are zones which also cannot be changed" (local government). The MoU implies mutual acknowledgement: "what is certain is that with the MoU on conservation partnerships... have acknowledged that it is a National Park area, if they are willing to sign the MoU, they acknowledge that the area they previously encroached on is a national park area" (NGO). The purpose of the MoU was to restore the function of the Rinjani forests, which were impacted by encroachment that converted forests into agricultural and plantation lands. This was done in a way that involved local people who encroached these lands.

\section{DISCUSSIONS}

Here we turn to key dimensions of principled engagement, shared motivation and capacity for joint action, set forth in the framework of collaborative governance theory. We do this by applying the framework to aspects of resolving the Bebidas conflicts.

\subsection{Principled Engagement}

This dimension is the precursor to the establishment of any dynamic collaboration, which involves convening many different perspectives and behaviors of 
the parties from each organization, group, or institution they represent (Emerson et al., 2012). In general, all partners understand what happened in this conflict because of their involvement. The element of 'discovery' highlighted the shared interests, illustrated from the statements across stakeholder groups. Shared interests, according to Emerson et al. (2012), involves a 'joint fact finding' process, which was clearly identified in the process to identify the lands in question in the National Park area, as well as subsequent initiatives. This 'discovery' element is the first step in making strategic designs for other elements under framework of collaborative governance theory (Kossmann et al., 2016), without which collaborative action will be very difficult to pursue.

The participants realized that collaborative action can be used as a solution to resolving conflict, even though the community initially did not consider such a possibility. Thus the 'definition' element was identified early on the process. Collaborative action was based on how to build communication through dialogue. There were eight formal meetings recorded, involving village, sub-district, regional government officials, police, MRNP, NGOs, and representatives of the Bebidas community. Meanwhile, there was significant commitments to informal communication through personal meetings that were not documented but helped to build the key element of trust. The settlement process only made breakthroughs, however, in 2018 and an agreement was finally reached at the end of 2020. This shows that there are problems in the quality of 'deliberation'. This is in contrast to Fisher et al. (2020) where various expert groups were involved, such as researchers and NGOs that helped to design more effective dissemination of information to support conflict resolution through collaborative designs.

The findings show that while formal meetings are important, they are not strong enough to build trust and understanding, especially for those in the community who found it difficult to accept formal knowledge about who is allowed to occupy those lands. On the other hand, dialogue that is built in an unconventional way helps provide an effective forum for raising awareness, understanding diverse viewpoints, technical understanding, and building acceptable resolution. This finding revises Ansell \& Gash (2008) statement that face-to-face dialogue models should be applied in more 'ceremonial' and 'conventional' approaches, especially for long-term collaborations. In Bebidas, the dialogue forum can be carried out in an informal way, which are 'casual' and 'flexible' and helps to garner attention and trust from the community. This is why the 'determination' aspect of the framework has some weaknesses in setting a clear and routine agenda in the case of formal meetings being held.

\subsection{Shared Motivation}

Shared motivation, also more broadly called social capital elsewhere, is generated from a complex 'principled engagement' process in making relationships between elements (Putnam, 2000). This allows stakeholders to generate consensus and build forms of collective actions (Emerson et al., 2012). Establishing trust and mutual understanding in this conflict faced many obstacles, however, namely a long process that required significant resources. The Bebidas community was the last party to understand the importance of collaboration as a solution to this conflict, due to the knowledge imbalance factor influenced by local actors involved in political divisions. This factor might arise due to the limited access to information, the difference of socioeconomic backgrounds and access to resources, thus affecting perspectives on moving 
towards pathways to resolution. This problem can be solved by increasing public consultations and capacity building to convey information, which can be designed through training and mentoring, as stated by Fisher et al. (2020) so that "mutual trust" and "mutual understanding" can be created. Understanding and trust building becomes a meaningful driving force in legitimizing strategic decisions in collaboration forums.

Internal Legitimacy in collaborative action includes representativeness, transparency, and acceptance. The element of representation is reflected in all parties participating in the dialogue, especially from the presence of MRNP and Bebidas village community. In terms of transparency, the findings indicate that the community did not clearly provide strong evidence of customary land ownership. The government, on the other hand, was quite transparent in providing data and information related to conservation regulations, boundaries of conservation areas through legal documentary evidence and intentions to resolve conflicts with collaboration. A transparent process increased the credibility of the forum and avoided the practice of delegitimizing the outputs which resulted from collaborative actions.

In a collaboration forum, each stakeholder has different capacities, resources, and networks (power imbalances), so it is possible for weak participants becoming vulnerable to be manipulated/pressured by superior ones. (Ansell \& Gash, 2008). However, it can be avoided if the principles of equality, representativeness and transparency are upheld. The government and Bebidas residents both established amenable rights and responsibilities, agreeing to be involved in an open process towards those ends, whereby strategic decisions were made and implemented by the parties together. Trust, understanding, and high legitimacy can result in a strong 'shared commitment' from stakeholders to continue to push for conflict resolutions that transform into new forms of collaborative governance.

\subsection{Capacity for Joint Action}

Collaborative networks stimulated the development of capacity to take joint action (Emerson et al., 2012). Findings reveal that the 'procedural and institutional arrangements' in this collaboration is implicit. T here we re no written standards or rules, position or authority of each stakeholder. Although not explicitly stated, the relationship between stakeholders in the forum was quite 'smooth', far from being hierarchical and complicated by common power differentials that usually take place with such stakeholders elsewhere. Each stakeholder understood their respective roles and authority in the collaboration process. This finding goes against conventional opinion described in Emerson et al. (2012), which stated that all matters relating to rules, protocols and structures should be explicit, especially when the collaboration is likely to be long term. On the contrary, this study shows that the structures and protocols do not have to be explicit, but can instead be implicit, and the dynamics of collaboration can still work in generating joint capacities.

Collaboration between stakeholders also create joint capacity in terms of 'leadership', in which MRNP and local government had the most prominent leadership roles among stakeholders. Their roles were to actively encourage the convening of meetings, to create a process, to disseminate balanced information for internal and external parties, to design a fair collaboration process so that the weaker parties (community) can play an active role, and to encourage the creation of a solution to this conflict. The findings regarding the leadership role are supported by Ansell \& Gash (2008), Emerson et al. (2012), Vangen \& Huxham (2003). 
Collaboration can produce 'knowledge.' However, there are still obstacles for the community, and knowledge gaps still occurred. With limited knowledge and understanding among the community, particularly in formal jurisdictional affairs, they become vulnerable parties to manipulation, by a number of individuals for particular interests. This was exactly what initially happened in the Bebidas case. The results of this study are also in line with the findings of Fisher et al. (2020), Rokhim et al. (2020), Riggs et al. (2016) that limited knowledge and understanding of regulations, social conditions, and scientific-based knowledge have caused forest communities to lose in case of disputes/conflicts, especially with authorities and/or corporations related to land and natural resource management. The existence of 'resource' support in various contexts is also a capacity that results from collaborative action. There were many forms of support that resulted from the collaboration, such as financial support allocated by MRNP and the local government, human resource support, and technical and administrative support for the creation of conflict resolution initiatives, such as the formation of Pokdarling and Pokdarwis that included financial, staffing, and also administration support.

\subsection{Outputs of Collaborative Action}

Collaborative action is the result of the aggregation of the three dimensions of principled engagement, shared commitment and capacity for joint action, which coalesced as a conflict resolution initiative in the form of creating new rules, monitoring and evaluation, construction of new facilities and infrastructure, and implementation of new management practices (Emerson \& Nabatchi, 2015). Several forms of settlement have been generated in collaborative dynamics, namely the signing of a Mutual Agreement (MA) and MoU between MRNP and the Bebidas community, which was based on a conservation collaboration (Regulation of Director General of Natural Resources and Ecosystem Conservation No. P.6/2018). This formed the basis for conflict resolution through community empowerment and forest restoration activities.

A number of case studies show that collaboration is more likely to continue when goals and benefits become relatively concrete as indicated by the emergence of 'small wins' (Ansell \& Gash, 2008). The resulting MA and MoU acted as the 'small wins.' The consensus in this case is closer to collective collaborative action on resources between the community and the government to restore forest functions, where the government provides funds and manages administration, while the community provides human resources and benefits from the arrangements. Thus, the two agreements have administratively ended the conflict, leading to a new peaceful condition through collaboration.

\section{CONCLUSION}

Broadly speaking, the Bebidas case show that dimensions of principled engagement were clearly identified, which shows that parties could express their views on the conflict. They formed a collaboration forum with the aim of resolving conflicts. Shared commitments were built through a long process by building trust. The problem of knowledge gaps influenced the process of building mutual trust and mutual understanding and creating obstacles that resulted in a protracted conflict resolution process. Legitimacy was created when partnership between parties could be achieved properly, which resulted in continued mutual commitments.

In terms of capacity for joint action, collaboration created procedural and 
institutional arrangements that tend to be implicit rather than explicit. The leadership role was evident among the MRNP and local government, which exhibited a willingness to act differently and encouraged parties to participate in dialogue, information dissemination, and initiating conflict resolution. Technical support such as human resources, administrative support, and financial support were also provided to pursue the collaboration. The collaboration forum resulted in two organizations implementing new management practices, namely the Pokdarling and Pokdarwis. The creation of a Mutual Agreement and MoU was a turning point from conflict to collaboration that creates an atmosphere of peace and harmony. Taken together, these outcomes provided the basis for the community benefiting from the process, and also resulted in restoration initiatives for the park.

One of the underlying factors driving the conflict is the lack of access to land availability for the surrounding community. Going forward there will need to be greater attention to ensuring that the community can explore opportunities for cultivating land in a legal way, without having to destroy and change the function of the forest into commercial agricultural land. The establishment of a Geopark and other ecotourism potential could be one pathway forward, especially if it grows out of the trust already established. The partnership conservation scheme (P.6/2018) can be applied to several buffer zones (locations adjacent to conservation areas) as well, so that similar tenure conflicts can be minimized in the future. Some of the programs and activities that can be applied include managing new tourist destinations with the involvement of local communities, seeding and tree planting activities that are handed over to the community and developing capacity building activities and technical capabilities. In overcoming the knowledge imbalances, it is necessary to consider a public consultation design through dissemination and training activities, as well as informal activities such as gatherings for knowledge transfer to the community in particular.

Competing interests: The authors declare that there are no conflicts of interests involved in this research.

Author contributions: Aryogito Nindyatmoko: wrote and edited all sections of article, established the structure of article, developed the theoritical framework, conducted interview, analysed and interpreted the results. Kristina: corrected of writing language and supervised research. Rina: evaluation and feedback.

Acknowledgments: Authors would like to thank the Faculty of Social and Political Science of Universitas Sebelas Maret for financial support; and thank to the head of Rinjani National Park Board for giving permission the interview to obtain data. Our sincere appreciation is also to the anonymous reviewers who provided extensive feedback and comments.

\section{REFERENCES}

Ansell, C., \& Gash, A. (2008). Collaborative governance in theory and practice. Journal of Public Administration Research and Theory, 18(4), 543-571. https://doi.org/10.1093/jopart/mum032

Bar-Tal, D. (2000). From intractable conflict through conflict resolution to reconciliation: Psychological analysis. Political Psychology, 21(2), 351-365. https://doi.org/10.1111/0162-895X.00192

Burton, J. W. (1988). Conflict As A Political System. George Mason University.

Dhiaulhaq, A., De Bruyn, T., \& Gritten, D. (2015). The use and effectiveness of mediation in forest and land conflict transformation in Southeast Asia: Case studies from 
Cambodia, Indonesia and Thailand. Environmental Science and Policy, 45(November), 132-145. https://doi.org/10.1016/j.envsci.2014.10.009

Elfversson, E. (2016). Postprint Peace from below: Governance and peacebuilding. Journal of Modern African Studies, 54(3), 469-493. https://doi.org//dx.doi.org/10.1017/S0022278X16000227

Emerson, K., \& Nabatchi, T. (2015). Collaborative Governance regime. Georgetown University Press.

Emerson, K., Nabatchi, T., \& Balogh, S. (2012). An integrative framework for collaborative governance. Journal of Public Administration Research and Theory, 22(1), 1-29. https://doi.org/10.1093/jopart/mur011

Fisher, J., Stutzman, H., Vedoveto, M., Delgado, D., Rivero, R., Quertehuari Dariquebe, W., Seclén Contreras, L., Souto, T., Harden, A., \& Rhee, S. (2020). Collaborative Governance and Conflict Management: Lessons Learned and Good Practices from a Case Study in the Amazon Basin. Society and Natural Resources, 33(4), 538-553. https://doi.org/10.1080/08941920.2019.1620389

Fisher, L. A., Kim, Y. S., Latifah, S., \& Makarom, M. (2017). Managing forest conflicts: Perspectives of Indonesia's forest management unit directors. Forest and Society, 1(1), 8-26. https://doi.org/10.24259/fs.v1i1.772

Gabay, M., \& Alam, M. (2017). Forest Policy and Economics Community forestry and its mitigation potential in the Anthropocene: The importance of land tenure governance and the threat of privatization is. Forest Policy and Economics, 79, 26-35. https://doi.org/10.1016/j.forpol.2017.01.011

Kalabamu, F. T. (2019). Land tenure reforms and persistence of land con $\mathrm{fl}$ icts in SubSaharan Africa - The case of Botswana. Land Use Policy, 81, 337-345. https://doi.org/10.1016/j.landusepol.2018.11.002

Katz, N., \& McNulty, K. (1994). Conflict Resolution. Maxwell. https://www.maxwell.syr.edu/uploadedFiles/parcc/cmc/ConflictResolution NK.pdf

Kossmann, C. M., Behagel, J. H., \& Bailey, M. (2016). Action and inertia in collaborative $\begin{array}{llll}\text { governance. } \quad \text { Marine } & \text { 21-30. }\end{array}$ https://doi.org/10.1016/j.marpol.2016.06.007

Larson, A. M. (2013). Tenure rights and access to forests: $A$ training manual for research. CIFOR.

Larson, A. M., Brockhaus, M., Sunderlin, W. D., Duchelle, A., Babon, A., Dokken, T., Pham, T. T., Resosudarmo, I. A. P., Selaya, G., Awono, A., \& Huynh, T. B. (2013). Land tenure and REDD+: The good, the bad and the ugly. Global Environmental Change, 23(3), 678-689. https://doi.org/10.1016/j.gloenvcha.2013.02.014

Lokadata. (2019). Konflik agraria di Indonesia, 2010-2019. Lokadata. https://lokadata.beritagar.id/chart/preview/konflik-agraria-di-indonesia2010-2019-1582192899

Lombard, M. (2016). Land conflict in peri-urban areas: Exploring the effects of land reform on informal settlement in Mexico. Urban Studies, 53(13), 2700-2720. https://doi.org/10.1177/0042098015603569

Pritchard, M. F. (2016). Land Use Policy Contesting land rights in a post-conflict environment: Tenure reform and dispute resolution in the centre-West region of Côte d' Ivoire. Land Use Policy, 54, 264-275. https://doi.org/10.1016/j.landusepol.2016.02.022

Purnomo, E. P., \& Anand., P. (2014). The Conflict of Forest Tenure and the Emergence 
of Community Based Forest Management in Indonesia. Journal of Government and Politics, 5(1), 20-31. https://doi.org/10.18196/jgp.2014.0003

Putnam, R. D. (2000). Bowling Alone: The Collapse and Revival of American Community (1st edition). Simon \& Schuster.

Riggs, R., Sayer, J., Anne, R., Sayer, J., Margules, C., \& Klintuni, A. (2016). Forest tenure and conflict in Indonesia: Contested rights in Rempek Village, Lombok. Land Use Policy, 57, 241-249. https://doi.org/10.1016/j.landusepol.2016.06.002

Rokhim, R., Januari, A. D., Atik, U., Shara, S., \& Rusdayanti, N. (2020). Palm oil social conflict resolution and mediation in Jambi. Cogent Social Sciences, 6(1). https://doi.org/10.1080/23311886.2020.1812831

Sahide, M. A. K., Fisher, M. R., Maryudi, A., Yee, G., Supratman, S., \& Alam, S. (2019). The bureaucratic politics of conservation in governing land conflict: A typology of capacities. MethodsX, 6, 2536-2543. https://doi.org/10.1016/j.mex.2019.10.022

Silima, T. (2016). Good Governance and Conflict Resolution in Africa. Journal of Public Administration and Development Alternatives, 1(1), 1-14. https://hdl.handle.net/10520/EJC-933727cdb

Vangen, S., \& Huxham, C. (2003). Enacting Leadership for Collaborative Advantage: Dilemmas of Ideology and Pragmatism in the Activities of Partnership Managers. British Journal of Management, 14, 61-76. https://doi.org/10.1111/j.14678551.2003.00393.x

Werner, W. (2018). Land tenure and governance on communal land in Namibia. The Second National Land Conference, 1-29.

Wirawan, A. B., Utama, S., Suratno, I. R., \& Tambunan, J. R. (2019). Spatial Planning, Land Tenure, and Increasing Conflicts Over Land Claims in Sumatera and Kalimantan: Economic Development, Policy Dynamics, and the Pace of Investment (pp. 1-28). The Urban and Regional Development Institute (URDI).

Zartman, I. W., \& Faure, G. O. (2005). Escalation and Negotitation in International Conflicts. In Escalation and Negotiation in International Conflicts (1st ed.). Cambridge University Press. https://doi.org/10.1017/CB09780511550584.001 